\title{
Obituaries
}

\section{Jean Ginsburg}

Clinician and researcher who pioneered new areas of women's health

In 1971 a friend of mine was referred to Jean Ginsburg for possible thyroid disease. She came away with a diagnosis of probable anxiety. The experience might have been embarrassing but wasn't because, typically, Jean Ginsburg took every patient seriously and did her best for them. She was equally interested in patients whose diabetes, infertility, or thyroid disorders had been misdiagnosed as neurosis. She helped patients with complex problems, such as hirsute women, or people of indeterminate gender.

Dr Ginsburg was a polymath. One of a small group of postwar women doctors with a serious interest in women's health, she was a founder member of the British Fertility Society and an active member of the Endocrine Society. In the 1960s her work on female subfertility put her at the forefront of gonadotrophin use, now crucial to in vitro fertilisation. She was also a clinical physiologist and an expert on the circulation, and had a wide interest in endocrinology. She got her male colleagues to take quantities of $\mathrm{B}$ vitamins so that they had hot flushes of memorable proportions; they loved her nevertheless.

She helped to establish the academic endocrinology department at the Royal Free Hospital and set up one of the first menopause clinics in Britain. Initially she was a physiologist, but after taking a research fellowship-cum-lectureship in obstetrics she became interested in women's health, which was to become her life's work.

\footnotetext{
Advice

We will be pleased to receive obituary notices of around 250 words. Pressure on space means that in most cases we will be able to publish only about 100 words in the printed journal, but we can run a fuller version on our website. We will take responsibility for shortening. We do not send proofs. Good quality, original photographs are welcome. Please give a contact telephone number and, where possible, supply the obituary on a disk or by email to obituaries@bmj.com We need to know the year of birth and exact date of death of the deceased, and we prefer obituaries to state the cause of death. Please spell out abbreviations.
}

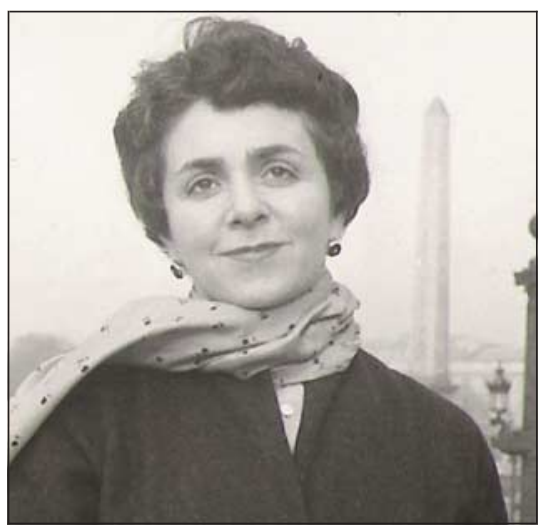

Jean Ginsburg-she had no middle names-was born in 1926, the daughter of newly arrived Jewish political refugees from revolutionary Russia. Her father, Naum Ginsburg, a civil engineer, had sheltered Trotsky in his home in St Petersburg when he was on the run from Tsarist troops before the Russian Revolution. He was imprisoned for this. Her mother, Anya Bielenky, a pianist who had studied at the Conservatoire in $\mathrm{St}$ Petersburg, went with a purse full of money to a Bolshevik general she knew and got her husband freed. Later, they fled to London, arriving in 1921.

Jean had a succession of scholarships. At Oxford she did her preclinical work and an honours degree in physiology. She was one of the first women to graduate from $\mathrm{St}$ Mary's Hospital Medical School, London. In 1954, two years after qualifying, she took a research fellowship in physiology and medicine at St Thomas's Hospital. Here she worked in the Sherrington School of Physiology under the famous Henry Barcroft; her main interest was the circulation and she was a pioneer of venous occlusion plethysmography. She and her colleagues would inject themselves, and medical student volunteers, with insulin to induce hypoglycaemia and, painfully, follow the effects on arterial blood flow.

In 1961 she became a research fellow and senior lecturer in the obstetrics department at Charing Cross Hospital, where she developed the interest in women's health that determined her future career. In 1966 she was appointed senior lecturer and consultant endocrinologist at the Royal Free Hospital, and she remained there, pursuing research to the end of her life. After she retired from clinical work she became an indefatigable medicolegal expert.

Jean Ginsburg was the author of many research papers and wrote one book, The Circulation in the Female from the Cradle to the Grave (1989) and co-edited two more, Drug Therapy in Reproductive Endocrinology (1995) and Sex Steroids and the Circulatory System (1987). Age did not wither her zest for research, nor pregnancy interrupt it-she monitored her circulation for research purposes during her third labour, stopping only to be delivered of her daughter.

In 1968 she was a passenger in a car when a lorry came out of a side turning and crashed into her, breaking both her arms and legs and causing other injuries. She spent three months in Paddington Green Hospital. Though she was warned that she would never walk again, she shuffled up and down stairs in a sitting position and eventually got back on her feet, though she always walked with a stick. At the end of her life, when she had kidney cancer, she would sit working in her hospital bed, despite the drain in her chest and blood transfusion in her arm.

After she retired from the NHS she continued in private practice, carried on with her research, and was invited to speak around the world. She was taken up by the media over the issue of pollution reducing male fertility (immensely enjoying the birth of a grandchild at the same time).

She loved music and was a fine pianist. A charitable foundation (www.jeanginsburg. com) has been established in her memory and will fund scholarships in music and medicine.

She leaves a husband, Jack Henry; two sons; and a daughter. [CAROLINE RICHMOND]

Jean Ginsburg, consultant endocrinologist Royal Free Hospital, London, 1966-86 (b London 1926, q Oxford/St Mary's Hospital, London, 1951; FRCP), d 8 April 2004.

Longer versions of these obituaries are available on bmj.com 


\section{Simon John Boniface}

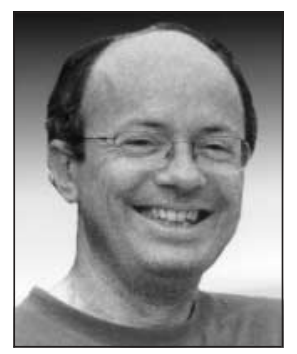

Consultant neurophysiologist Addenbrooke's Hospital, Cambridge (b 1959; q University College London 1983; MA, MD, FRCP), died from nocturnal seizure on 27 November 2003. Simon had an enduring passion for clinical neuroscience and for a wide range of outside interests, including the music of Elvis Costello. After training in neurology and ophthalmology he settled on a career in neurophysiology. He undertook an MD on transcranial magnetic stimulation while working as a Medical Research Council training fellow at the Radcliffe Infirmary in Oxford. In 1995 he was appointed to the first full time consultant position in neurophysiology at Addenbrooke's Hospital. He co-edited a book, Plasticity in the Human Nervous System. Separated from his wife, Maria, he remained close to his three children. He was fortunate to have found a new soulmate, Sara. [JoHn Hodges]

\section{Fritz Buchthal}

Former professor of neurophysiology Copenhagen, Denmark (b Witten, Germany, 1907; q Berlin 1932), d 24 December 2003.

Fritz Buchthal's principal contribution to medicine was to help turn scientific experiment into the now daily indispensable clinical investigation of patients with nerve and muscle disease. For many years he was the dominant figure in the field, teaching postgraduates from all over the world and receiving many honours. When too old to hold an official position in Denmark he was invited to direct the laboratory at the National Institutes of Health in Washington DC. He then settled in Santa Barbara, California, and consulted weekly at the Children's Hospital in San Francisco until he was 90. His wife, Margaret, predeceased him. [J PAYAN]

\section{Mary Graham Findlay}

Former medical superintendent Rainy Women's Hospital, Madras, India (b Aberdeen 1920; $q$ Edinburgh 1943), died from left ventricular failure with pneumonia on 8 April 2004.

Mary Findlay followed in her mother's footsteps as a medical missionary, going first to Kailimpong in north India. In 1947 she joined her parents in Mukden (now Shenyang), Manchuria, working in a women's clinic under the aegis of the Church of Scotland. In 1950 the Communist Chinese government took over, and she returned to Scotland, but later went back to India, becoming the senior doctor at Rainy Women's Hospital in Madras. In 1967 she joined a general practice partnership in Leven, Fife, where she remained until retirement. In the 1980s she returned to Manchuria to teach medical English. [IAN D Findlay, A Graham Findlay]

\section{Percy Ellis Thompson Hancock}

Former consultant physician Royal Free and Royal Marsden hospitals, London (b 1904; $q$ Cambridge/St Bartholomew's Hospital, London, 1931; FRCP), d 8Jan 2004.

Percy Thompson Hancock started as a registrar at the Royal Marsden in 1938. He was senior physician there in the 1950 s and 1960s when chemotherapy emerged as a new treatment for cancer and he played a crucial part in the new developments. Percy was appointed the first director of clinical research at the hospital. He started the first well woman clinic to screen for breast cancer. He won the National Milk Challenge Trophy in 1952 with his pedigree Ayrshire cattle. Predeceased by his first wife, "Blue," and his second wife, Laurie, he leaves two daughters. [Trevor Hudson]

\section{Jurek Lister}

Former consultant psychiatrist West Glamorgan Health Authority, Swansea (b Poznan, Poland, 1919; q Cardiff 1951; FRCPsych), d 2 April 2004.

His undergraduate medical studies in Warsaw were interrupted by the second world war, when he was interned by the Russian authorities. On being released, he had lost half his body weight. In his book Poles Apart (1997) he described the long and perilous journey that brought him to Britain. After joining up with the Polish forces, he was parachuted into Greece, where he liaised with the partisans. Having reached Italy, he restarted his medical studies. He was demobilised in Britain, and was eventually accepted as a student at the Welsh National School of Medicine. In 1955 he took up psychiatry, becoming a consultant at Cefn Coed Hospital, Swansea, in 1963. He leaves a wife, Barbara, and three children. [Tom Davies]

\section{Martin Littlewood}

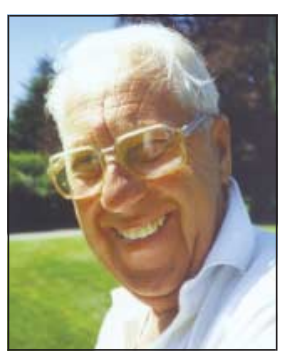

Former consultant in plastic surgery Whiston Hospital, Merseyside (b Guernsey 1923; $q$ Cambridge/University College Hospital, London 1946; FRCS), d 25 March 2004.
Martin started his career in plastic surgery in Gloucester. He moved to Liverpool as senior registrar, and was appointed consultant there in 1960. He undertook a fellowship in Buffalo, New York, at the head and neck surgery unit at Roswell Park, and on return to Liverpool this, together with cleft lip and palate surgery, formed the basis of his practice until he retired in 1985 . He remained active in retirement, building up a large medicolegal practice, enjoying golf, and tending his magnificent garden. He leaves a wife, Christena; three daughters; and three grandchildren. [SHEELAGH LITTLEWOOD, Clare Littlewood]

\section{Elizabeth Pais}

Former general practitioner Hove (b India 1909; q Lady Hardinge College, Delhi, India, 1935;DRCOG), d 2 April 2004.

She was a chief medical officer in India before being appointed professor of anatomy at Lady Hardinge College, Delhi. After marrying a doctor she worked in Mangalore before emigrating to Tanganyika, where she and her husband worked in the Aga Khan Hospital in Dar es Salaam and later set up a general practice and a maternity home. Her husband died in 1959, leaving her to continue singlehanded. In 1967 she left Tanzania for the United Kingdom and settled in Hove, East Sussex, where she set up in general practice. She leaves three children and seven grandchildren. [W A PAIS]

\section{William Porteous Small}

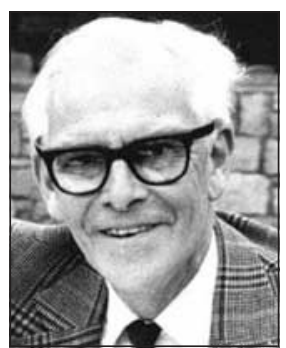

Former general and gastrointestinal surgeon Western General Hospital, Edinburgh (b Edinburgh 1920; q Edinburgh 1942; FRCS $E d, F R C P E d, C h M, V R D)$, died from prostate cancer on 25 March 2004.

After graduation Bill served in the Royal Naval Volunteer Reserve, retiring as surgeon commander. Following training in Edinburgh he was appointed consultant surgeon in 1955 . He pioneered surgical audit with a gastric follow up clinic for patients who had undergone surgery for duodenal ulcer. His paper in the New England Journal of Medicine (NEJM 1982;307:519-22) on late mortality after surgery for peptic ulceration showed that smoking significantly increased patients' chances of requiring surgery and significantly shortened life expectancy. Bill enjoyed cycling, woodwork, gardening, tuneless whistling, the Friends of the Hospital, and the kirk. He leaves a wife, Tordis; three sons and two adopted daughters; and seven grandchildren. [MARTIN EASTwOOD] 